\title{
Decolonizing English Language Teaching in Colombia: Epistemological Perspectives and Discursive Alternatives ${ }^{1}$
}

\author{
Descolonizando la enseñanza del idioma inglés en \\ Colombia: perspectivas epistemológicas y alternativas \\ discursivas
}

Yamith José Fandiño-Parra²

Citation/ Para citar este Artículo: Fandiño-Parra, Y. (2021). Decolonizing English Language Teaching in Colombia: Epistemological Perspectives and Discursive Alternatives. Colomb. Appl. Linguistic. J., 23(2), pp. 166-181.

Received: 13-Oct.-2020 / Accepted: 18-Aug.-2021

DOI: https://doi.org/10.14483/22487085.17087

\begin{abstract}
In times of geocultural subalternization of knowledge and education, English language teaching (ELT) is torn between subalternizing policies and subjectivating practices. Within this context, ELT teacher educators face policies and discourses aimed at framing their teaching practices, professional lives, and research agendas. However, at the same time, they are expected to engage in practices and processes that allow for personal adaptation and social change. Amid this ambivalence, this reflection paper makes a call to decolonize ELT in Colombia. To this effect, this paper reviews some basic epistemological perspectives such as colonialism and decolonial studies. Then, it proposes the decolonization of ELT, along with a grammar of decoloniality based on discursive alternatives about power, knowledge, and being with the potential of bringing about a transformative teacher subjectivation. The main conclusion is that the Colombian ELT community needs to first deconstruct dominant structures and strategies that enact epistemic and cultural dominance of the global north, and then construct alternative discourses and practices that acknowledge and disseminate the singularities of its knowledge and culture.
\end{abstract}

Keywords: decolonization, educational policy, English language teaching in Colombia, teacher education, teaching, teaching practice

\section{Resumen}

En tiempos de subalternización geocultural del conocimiento y la educación, la enseñanza de la lengua inglesa (ELI) se debate entre políticas subalternizantes y prácticas subjetivantes. En este contexto, los formadores de maestros de lengua inglesa enfrentan políticas y discursos orientados a enmarcar sus prácticas docentes, vidas profesionales y agendas de investigación. Sin embargo, al mismo tiempo, se espera que participen en prácticas y procesos que permitan la adaptación personal y el cambio social. En medio de esta ambivalencia, este artículo de reflexión hace un llamado a descolonizar la ELI en Colombia. Para ello, este artículo revisa perspectivas epistemológicas básicas como el colonialismo y los estudios descoloniales. Luego, propone la descolonización de ELI junto con una gramática de

1 This paper is part of the theoretical framework of the doctoral dissertation I am working on as a student of the Ph.D. program in Education and Society at Universidad de la Salle in Bogotá, Colombia. It also belongs to my work as a researcher of the research group, "PREVADIA: Problem Solving, Evaluation, and Learning Difficulties".

2 Universidad de la Salle, Bogotá, Colombia. ORCID (D): https://orcid.org/0000-0002-5567-5465. yfandino@unisalle.edu.co 
la descolonialidad basada en alternativas discursivas sobre el poder, el conocimiento y el ser con el potencial de inducir una subjetivación docente transformadora. La principal conclusión es que la comunidad colombiana de ELI necesita primero deconstruir las estructuras y estrategias dominantes que promulgan el dominio epistémico y cultural del norte global para luego construir discursos y prácticas alternativas que reconozcan y diseminen las particularidades de su conocimiento y cultura.

Palabras clave:descolonización, política educacional, enseñanza de la lengua inglesa en Colombia, formación de docentes, docencia, práctica pedagógica

\section{Introduction}

\author{
Decolonizing education can be understood \\ not necessarily/exclusively as negating existing \\ educational approaches, but instead as encouraging \\ moments which 'interrupt' existing dominant framings \\ of education. Such moments have the potential to \\ open 'spaces' for doing education otherwise
} (Biestra, 2013, as cited in Pirbhai-Illich et al., 2017, p. 7).

In recent years, Colombian teachers, researchers, and stakeholders have sought to reflect on and analyze English language teaching (ELT). From theoretical positions such as sociocultural constructivism or reflective hermeneutics, as well as from methodological approaches such as phenomenological interpretivism or emancipatory socio-criticism, they have designed, implemented, and evaluated projects aiming to propose pedagogical guidelines and understand what and how English is taught in schools, institutions, and universities. Examples of the use of such approaches can be found in research projects carried out in the Languages School at Universidad de Antioquia or the Faculty of Human Sciences at Universidad Nacional de Colombia. By the same token, there have been studies of the curricular bases of reforms and guidelines designed mainly to achieve better results in the quality, effectiveness, and efficiency of teaching. Examples of the use of such studies are available in master's Programs such as the one in Pedagogical Mediation in English Learning at UNAD or the one in Applied
Linguistics to the Teaching of English Language at Universidad Distrital Francisco José de Caldas.

Undoubtedly, these projects have made it possible to unveil and refute mercantilist and neoliberal approaches. They have opened spaces to rethink and remodel practices and discourses in the teaching of English as a foreign language (EFL) in our nation. However, this reflection paper argues that, although necessary and useful, these advances are not enough because, when it comes to ELT, colonial perspectives still prevail, circumscribing and limiting the nature and scope of educational reforms and curricular projects (see Soto-Molina and Méndez, 2020; Torres-Rocha, 2019).

In the last three decades, English language in Colombia seems to be put in a privileged position with respect to Spanish (L1) and aboriginal languages. This privileged position appears to be based on the central role English has had in the latest educational reforms and curricular projects promoted by the last governments. Nonetheless, a review of such reforms and projects from the perspective of colonialism and decolonial studies in ELT reveals that the discourses and practices present in government decrees and regulations move between subordinating policies and subjectivating practices. This is so because, on the one hand, foreign language teachers are asked to comply with guidelines and mechanisms that circumscribe their teaching work, their professional life, and their research itineraries. On the other hand, these teachers are expected to experience practices and processes that demand personal appropriation, collegial action, and social transformation. This ambivalence between subalternization and subjectivation requires openness to disobedient perspectives and undisciplined alternatives that allow the decolonization of ELT. To this end, this reflection article initially reviews colonialism and decolonial studies to later move towards a description of the grammar of decoloniality and an exposition of the empowerment, education, and subjectivation of foreign language teachers. Ultimately, readers are expected to conclude that the Colombian ELT community requires an epistemic turn that allows it to deconstruct discourses and practices that not only impose the thought and culture of 
the global north, but that, above all, mobilize the knowledge and the culture of teachers, students, and institutions of the global south.

\section{Colonialism}

World history is filled with stories of empires that dominated vast territories and peoples. Despite this, the domination of the global north in Latin America, Africa, and Asia marked a turning point in history ${ }^{3}$. This has impacted not only the economy and the science of the world, but it has also shaped the ethical-political, sociocultural, and discursive dynamics among continents, states, and peoples ever since. The dominance of the global north is, then, a perfect example of colonialism, as it refers "to a large-scale political and economic system that allows one geopolitical entity (such as a nationstate or city-state) to establish controls beyond its traditional geographic borders in the service of increased profit or power" (Ahuja, 2017, p. 237). Besides, this colonialism has three fundamental attributes that have marked its nature and scope:

"(1) one society deprives another one of its autonomous development through control and reconfiguration, (2) the colonizers and the colonized are separated by a cultural gap, and (3) one ideology is disseminated to legitimize colonial expansion" (Osterhammel, 1997, as cited in Sommer, 2011, p. 189).

For his part, de Castro (2014) points out that the colonialism of the global north is characterized

"not only by the conquest of a territory and its population, or by the extraction of monetary, human, or material resources, as was the case in antiquity, but also... because it attempts to change the cultures of the populations conquered... In fact, this cultural change is often a prerequisite for the economic exploitation of the acquired territories" (p. 384).

3 According to Davis (2012), the global north is taken to include the industrialized, high-per-capita income, national political economies of which the majority are in the Northern Hemisphere. The global south describes those countries with high levels of poverty and comparatively low levels of industrialization, large numbers of which exist in the Southern Hemisphere.
The results of that cultural change are traceable to concepts such as class, gender, and race, which construct the attitudes of the colonizers and constrain the behaviors of the colonized. Thus, this colonialism consists of a cultural process of spreading and imposing discourses that establish discriminating hierarchies on a planetary scale. These hierarchies create a plethora of beliefs and ideologies that enable the permanence and reproduction of colonialism. In fact, much of that vision of the world persists today through colonial discourse and patronage.

Following Foucault, Ashcroft et al. (2007) define colonial discourse as a system with which dominant social groups construct reality and truth by imposing certain knowledges and values over dominated groups. To them, colonialism operates through such discourse as an instrument of power, supremacy, and subjugation. Concretely, colonial discourse is a "complex of signs and practices that organized social existence and social reproduction withing colonial relationships" (Ashcroft et al., 2007, p. 37). This complex institutes a particular myriad of statements and propositions about colonies, colonial peoples, and colonizing powers, within which acts of colonization take place. Apart from helping exercise rules of inclusion and exclusion, this discourse becomes the means within which the colonized come to see themselves, creating "a deep conflict in the consciousness of the colonized because of its clash with other knowledges (and kinds of knowledge) about the world" (Ashcroft et al., 2007, p. 37).

Together with the colonial discourse, colonialism uses colonial patronage. This refers to "the economic or social power that allows cultural institutions and cultural forms to come into existence and be valued and promoted" (Ashcroft et al., 2007. p. 38). In colonialism, patronage takes the form of the imposition of certain social institutions that influence the production of culture. It also implies the spread of ethno-centric ideas from the culture of the global north such as civilization and writing. Not only does colonial patronage recognize and endorse certain cultural activities of the colonizing societies over the colonized ones, but it also denies forms of culture that are key to the development of 
the cultural identity of the colonized. An example of such denial is the discredit assigned to the oral and the performative arts and other practices such as ceramics, weaving, and carving (Aschcroft et al., 2007).

As it may be assumed from the use of present simple in the previous paragraphs, I am suggesting that colonialism is far from over. In fact, I concur with Böröcz and Sarkar (2012) when they state that colonialism is an existing worldview, which can be defined as "a truly global geopolitical, economic, and cultural doctrine that is rooted in the worldwide expansion of global north capitalism that has survived until well after the collapse of most colonial empires" (p. 271). This doctrine has impacted three interrelated fields of domination: political-economic, social-institutional, and representational-symbolic.

The first field of domination helps understand the emergence of global capitalism and the making of what the global north is today, particularly western Europe and the USA. Such emergence results from two separated, but related processes: value transfer and devastation effect. The former consists of mechanisms (e.g., exploitation, taxation, slavery) that ensure transfer of natural resources from the colonies to the metropolis, whereas the latter consists of the destruction of the structures of the colonized through displacement, massacres, and monopolies. Both value transfer and devastation effect have enabled the global north to expand its geopolitical and economic supremacy.

The social-institutional field of domination provides evidence of the systematic use of force to produce massive dislocations of human beings in the service of capitalist production. Thousands of recruits are displaced from their regions to work in plantations, mines, infrastructures, and other constructions. Moreover, these populations are treated as inferior and disposable beings by the introduction of dehumanizing practices between the colonizers and the colonized, the colony and the metropolis. Some of those dehumanizing practices have opened room for transgressions such as labor and sexual exploitation", as well as human trafficking.

The third field of domination deals with the social representations of the colonized and the colonies. In fact, colonialism seeks to both limit the contexts where the colonized can represent themselves and ensure that those representations align with inferiority and negativity. As a result, the representations of the colonized tend to depict uncultured peoples in need of educators or belligerent masses in need of missionaries. Table 1 summarizes what I have stated about colonialism so far.

\section{Colonialism and English language teaching}

In English and the Discourses of Colonialism, Pennycook (1998) maintains that colonialism is not just a political or economic relationship legitimized through ideologies of racism or progress. Instead, he claims it is "a cultural process whose discoveries and trespasses are imagined and energized through signs, metaphors, and narratives" (Thomas, 1994, as cited by Pennycook, 1998, p. 16). One of the most influential narratives is the notion of English as an enlightened, rational, and superior language, whereas other languages are incomprehensible,

Table 1. Colonialism: features, elements, and fields of domination

\begin{tabular}{|c|c|c|}
\hline \multicolumn{3}{|c|}{ Colonialism } \\
\hline Features & Elements & Fields of domination \\
\hline $\begin{array}{ll}\text { - } & \text { Geopolitical entity } \\
\text { - } & \text { Large-scale political and economic } \\
\text { - } & \text { System } \\
\text { - } & \text { Cxpansion and domination } \\
\text { - } & \text { Cultural gand reconfiguration } \\
\text { - } & \text { Hierarchies }\end{array}$ & $\begin{array}{ll}\text { - } & \text { Colonial discourse } \\
\text { - } & \text { Colonial patronage }\end{array}$ & $\begin{array}{ll}\text { - } & \text { Political-economic } \\
\text { - } & \text { Social-institutional } \\
& \text { Representational-symbolic }\end{array}$ \\
\hline
\end{tabular}

Source: Author 
abnormal, and inferior. Using documentary research, he shows how the alleged richness, purity, vastness, and advancement of English substantiate the belief of its speakers as being the most competent thinkers. This supposed superiority has had lasting effect on the massive spread of English around the globe. Within this context, Pennycook (1998) argues that ELT is

a product of colonialism not just because it is colonialism that produced the initial conditions for the global spread of English, but because it was colonialism that produced many of the ways of thinking and behaving that are still part of Western cultures... ELT not only rode on the back of colonialism to the distant corners of the Empire but was also in turn produced by that voyage (p. 19).

Concretely, Pennycook maintains that ELT echoes constructions of colonialism through the native speaker/non-native speaker dichotomy, as well as the images of self and other. Additionally, he claims that ELT theories and practices enact cultures and ideologies of the global north that are in fact outcomes of colonialism. With this in mind, Pennycook (1998) and authors such as Sekhar (2012) and Hsu (2017) have pointed out that applied linguistics and TESOL suffer from a loud absence of discussion about colonialism, as these two disciplines have not undertaken major research studies about:

1. how colonialism operates in language and educational policies,

2. how colonialism permeates the development of ELT,

3. how colonialism frames expectations and stereotypes in ELT, and

4. how colonialism influences research agendas and school curricula in ELT.

In 2007, Pennycook maintained that there are three significant relationships between colonialism and ELT: historical, political-economic, and cultural. The first relationship suggests ELT has favored the spread of English as an imperial language, the provision of the English civilization to the world, and the production of docile and compliant workers.
The political-economic relationship alludes that ELT plays an important role in the structure of global inequality, as achieving certified proficiency in English has become an obstacle to accessing education, employment, and science. The cultural relationship implies that ELT influences the construction of embellished images of English, of its learners, and of its speakers. To overcome or alleviate these relationships, Pennycook claims that ELT must enact strategies "by which the marginalized detach themselves from the ideologies of the powerful, retain a measure of critical thinking, and gain some sense of control over their life in an oppressive situation" (Canagarajah, 2000, as cited in Pennycook, 2007, p. 22). Some of these strategies are (a) discursive appropriation (transforming English to integrate features from the mother tongue), (b) reinterpretation (using predominant discourses to suit one's own interests and ideologies,), (c) accommodation (using the language status and prestige to benefit one's agendas), and (d) linguistic appropriation (mingling English and a mother tongue to constitute a hybrid system) (Canagarajah, 2000).

Concerning Colonialism and ELT, Pishghadam and Zabihi (2012) explain that the concentric model of global English proposed by Kachru (1985) ${ }^{4}$ reflects an unequal state of power in which the inner circle maintains the gap between the colonizer and the colonized. Furthermore, the inner circle uses language as a tool of power to stereotype and degrade undifferentiated masses. Additionally, Pishghadam and Zabihi (2012) claim that most ELT professionals in the different circles are moved by a view of the field as a business designed to obtain economic gains. This means that the empowerment of learners of English is overshadowed by ELT professionals' concern with trade and investments.

4 Kachru's concentric model proposes three circles to account for the way in which English is spoken and used in the world. The first circle, the inner circle, contains the native speakers of countries considered English-speaking, specifically, the United States and the United Kingdom. They establish the official norms of the use of the English language. The second circle, the outer circle, includes the speakers of countries that were English colonies and that use English as their official language or as a second language (for example, India and Singapore). These countries have generated their own linguistic and discursive varieties. The third circle, an expanding circle, contains the countries in which English is used as a lingua franca or as a foreign language. 
Finally, Pishghadam and Zabihi (2012) claim that not only has ELT promoted the overgeneralization of non-native learners of English, but it has also been instrumental to the marginalization of other languages and cultures. As a result of such overgeneralization and marginalization, ELT is part of a cultural and linguistic imperialism that "has brought forth the idea that the global north's culture is superior to the culture of the periphery countries, as are the theories of English language teaching they tend to prescribe" (Pishghadam and Zabihi, 2012, p. 60).

From the perspective of overgeneralization and marginalization, two issues are worth discussing a bit further: (1) the images of self and others and (2) colonialism in school curricula. To Hasan Al-Saidi (2014), adopting otherness as a frame of reference helps one reveal how language and discourse are intertwined to configure realities and societies based on excluding opposites: the colonizer vs. the colonized, the north vs. the south, 'we' vs. 'they, etc. On the one hand, the self is frequently represented as structured, reasonable, tough, and good. Subsequently, speakers and members of particular social groups and cultural communities create discourses in which 'I' and 'We' are positioned in affirmative and approbatory ways. On the other hand, the others are often characterized as disorganized, irrational, weak, and bad. Then, speakers and members tend to use discourses in which 'You' and 'They' are symbolized in negative and disapproving ways (see Thielsch, 2019).
Regarding colonialism in school curricula, Masta (2016) claims that "curriculum contributes to the reproduction and perpetuation of social inequalities... [it] largely represents the interest of the dominant group" (pp. 185-186). An example of this situation is the negligence to attend to the experiences of the colonized and the failure to recognize the colonized as a valid source of educational knowledge. On the other hand, colonialism in school curricula generates a colonial blind discourse that normalizes "a continuous denial of the existence and presence of colonized people" (Masta, 2016, p. 186). In this regard, Charles (2019) states that

\section{decolonizing the curriculum means creating spaces and resources for a dialogue among all members of a school on how to imagine and envision all cultures and knowledge systems in the curriculum, and with respect to what is being taught and how it frames the world (p. 1).}

Table 2 synthesizes some on the main points discussed above.

\section{Colonialism and ELT in Colombia}

In Colombia, English language teaching has been intrinsically linked to what Phillipson (2009) calls linguistic imperialism. To him, this imperialism "focuses on how and why certain languages dominate internationally" (p. 11) and it "entails unequal resource allocation and communicative

Table 2. ELT from the perspective of colonialism

\begin{tabular}{|c|c|c|c|c|c|}
\hline English & Dichotomies & Relationships & Lack of studies & Strategies & Concentric model \\
\hline $\begin{array}{l}\text { - An enlightened, } \\
\text { rational, and } \\
\text { superior language } \\
\text { - A language spread } \\
\text { around the globe }\end{array}$ & $\begin{array}{l}\text { - The native speaker/ } \\
\text { non-native speaker } \\
\text { - The images of self } \\
\text { and other }\end{array}$ & $\begin{array}{l}\text { - Historical } \\
\text { - Political-economic } \\
\text { - Cultural }\end{array}$ & $\begin{array}{l}\text { - Colonialism in language } \\
\text { and educational policies } \\
\text { - Colonialism in the } \\
\text { development of ELT } \\
\text { - Colonialism and } \\
\text { expectations and } \\
\text { stereotypes in ELT } \\
\text { - Colonialism and research } \\
\text { agendas and school } \\
\text { curricula }\end{array}$ & $\begin{array}{l}\text { - Discursive } \\
\text { appropriation } \\
\text { - Reinterpretation } \\
\text { - Accommodation } \\
\text { - Linguistic } \\
\text { appropriation }\end{array}$ & $\begin{array}{l}\text { - Stereotypes and } \\
\text { degradation based } \\
\text { on the model of } \\
\text { 'Englishes' } \\
\text { - Business and } \\
\text { economic gains } \\
\text { - Overgeneralization of } \\
\text { non-native learners } \\
\text { - Marginalization of } \\
\text { other languages and } \\
\text { cultures }\end{array}$ \\
\hline
\end{tabular}

Source: Author 
rights between people defined in terms of their competence in specific languages, with unequal benefits as a result, in a system that legitimates and naturalizes such exploitation" (p. 12). It follows, then, that linguistic imperialism allows a powerful group to dominate a powerless one based on language, as well as to favor and position its power, resources, beliefs, and attitudes. Thereupon, linguistic imperialism can be summarized as (a) discriminating other groups on the basis of language, (b) privileging the powerful ideologically and structurally in terms of language, and (c) obtaining economic benefits based on rigged language policies.

To Veronelli (2015), ELT in Colombia is an example of what he calls coloniality of language. To him, this coloniality is an aspect of the dehumanization of the colonized through language policies based on epistemologies and ontologies from the global north. Among other things, this coloniality allows the colonial imaginary to presuppose the colonized as lessthan-human-beings with limited expressive and linguistic competences. Additionally, it allows a "disposition on the part of the colonizers against communicating and understanding, by reducing possible interlocutors to simple communication partners, and their languages to rudimentary tools of expressiveness" (Veronelli, 2015, pp. 4950). Ultimately, it makes the colonizers participate in monolinguistic acts in which they want others to know what they need while regarding their communal ways of life, their collective knowledge, and their creativity as not important.

When discussing colonialism, linguistic imperialism, and ELT in Colombia, Branschat (2019) indicates that EFL teachers seem to play a role in promoting linguistic imperialism, as well as in stimulating coloniality of language. This is so, as it appears to contribute to the propagation of beliefs, attitudes, and imaginaries that glorify English and marginalize other languages, especially aboriginal ones. In fact, they can be instrumental in spreading the idea that English is a means to obtaining economic and cultural power (see Guerrero, 2010 for a critical discourse analysis of this issue). Indirectly, EFL teachers may contribute to the idea that English deserves more investment in terms of resources and infrastructure than other languages, which promotes linguistic inequality. Additionally, Branschat criticizes the dominant role of the British Council in the coordination of foreign language policies, the use of the Common European framework of references for languages as the basis of curricular guidelines, and the mandatory use of English both in the Colombian education system as well as in programs of teacher education. To Branschat, these situations are examples of how the Colombian ELT community complies with the teaching of a powerful high market value language without much consideration of its implication in the minimization of the linguistic capital and linguistic human rights of Colombians.

For his part, Le Gal (2019) criticizes the unhealthy dependency of ELT in Colombia on foreign technologies and expertise. Initially, he discusses the businessification and corporatization of ELT resulting from imported teacher certification and teacher training, e.g., in-service certificate in English language teaching (ICELT) and teaching knowledge test (TKT). Furthermore, he disapproves of the adoption of foreign methodologies and imported materials without the necessary contextualization, or the development of own bets based on needs analysis and local research. Moreover, he complains about the promulgation of linguistic policies under foreign influence, as they generate an inclination towards international intervention and marketshaping activities in our country. In view of these situations, Le Gal (2019) makes a call for "a reappropriation of ELT by governmental institutions and for a model characterized by collective construction, where self-elaborated knowledge is of prime importance" (p. 170).

In Colombia, the businessification and corporatization of English courses, the adoption of imported methodologies and materials, and the promulgation of linguistic policies are all linked to what Bourdieu (1991) called linguistic capital. This capital can be understood as "the ability to speak a dominant language fluently as a social resource that may be helpful in gaining access to desirable goods and positions" (Valtonen, 2016, p. 159). Not speaking a dominant language such as English means one is vulnerable, as one cannot represent 
oneself in certain sociocultural and communicative events. Furthermore, not knowing English implies one cannot access high-quality education (cultural capital), superior jobs (economic capital), and prestige (symbolic capital) (Loos, 2000). As a result, beyond the teaching and learning of language skills and communicative competence, the ELT community needs to reflect about the implications of providing or denying access to certain communicative acts and linguistic exchanges. This is so, as these acts and exchanges enact and spread symbolic power, which is used by social groups and speakers to realize power in their relations. ELT is therefore far from neutral, as it functions as a means to achieving symbolic power and exercising power in relations. Here, I concur with Roth (2019) when she maintains that ELT "is associated with the promotion of particular forms of culture and knowledge and is associated with inequality, power, and hegemony" (p. 41). Table 3 synthesizes some of the main points discussed above.

\section{Decolonialization}

Colonialism in general and colonialism in ELT in particular demand a profound revision of what the teaching and learning of English as a foreign language means for a multicultural and plurilingual country such as Colombia. Particularly, it requires Colombian EFL teachers to voice their concerns, validate their epistemologies, and contend Eurocentric views of the world. In this line of thinking, Guerrero (2018) invites the Colombian
ELT community to "open spaces to re-examine the profession, to problematize the given, to expand the horizons of being an English teacher" (p. 128). Such problematization implies recognizing discriminating practices and homogenizing discourses, as well as acknowledging other ways of knowing and of doing things. Ultimately, it involves "tracing the continuities and discontinuities between the colonial logic of the status quo and a decolonial perspective [that] resorts on ecologies of knowledges to promote a dialogical relationship among different types of knowledges" (Guerrero, 2018, p. 129).

From this perspective, it is important to regard decolonization as an epistemological and political bet that emerges as a critical response to the colonializing practices and discourses perpetuated after the colonies were removed. Such bet seeks to overcome a state of cultural domination and epistemological hegemony by valuing the existence of a neglected discursive plurality and a disregarded cultural diversity. This bet has been discussed by several scholars in the last two decades, but examining these discussions goes beyond the aim of this reflection paper. However, a historical overview of some definitions and characteristics can help one identify the foundations of decolonization as a fertile ground to dislocate subalternizing power, knowledge, and being, as well as to mobilize intercultural dialogue, social justice, ethnic diversity, and human dignification. Table 4 summarizes some foundational definitions and characteristics of decolonization offered in recent years by intellectuals from the global south.

Table 3. Colonialism in the Colombian ELT community

\begin{tabular}{|c|c|c|c|}
\hline Linguistic imperialism & Coloniality of language & $\begin{array}{l}\text { The teaching of English as } \\
\text { a foreign language }\end{array}$ & $\begin{array}{l}\text { Dependency on foreign } \\
\text { technologies and expertise }\end{array}$ \\
\hline $\begin{array}{ll}\text { - } & \text { Language inequality } \\
\text { - } & \text { Discrimination } \\
\text { - } & \text { Privilege } \\
& \text { Economic benefits }\end{array}$ & $\begin{array}{l}\text { Dehumanization of } \\
\text { the language of the } \\
\text { colonized } \\
\text { An imaginary of limited } \\
\text { expressive and linguistic } \\
\text { competences }\end{array}$ & $\begin{array}{ll}\text { - } & \text { Promotion of linguistic } \\
\text { imperialism } \\
\text { - Stimulation of } \\
\text { coloniality of language } \\
\text { Minimization of the } \\
\text { linguistic capital and } \\
\text { linguistic human rights } \\
\text { of Colombians }\end{array}$ & $\begin{array}{ll}\text { - } & \text { Adoption of foreign } \\
\text { methodologies and } \\
\text { imported materials } \\
\text { Promulgation of } \\
\text { linguistic policies under } \\
\text { foreign influence } \\
\text { International } \\
\text { intervention and } \\
\text { market-shaping } \\
\text { activities }\end{array}$ \\
\hline
\end{tabular}

Source: Author 
Table 4. Some definitions and characteristics of decolonization

\begin{tabular}{|c|c|c|c|}
\hline Year & Author & Definition & Characteristics \\
\hline 2006 & Maldonado & $\begin{array}{l}\text { Decolonization refers to the dismantling of power relations and } \\
\text { conceptions of knowledge that promote the reproduction of racial, } \\
\text { geopolitical and gender hierarchies that were created or that found new } \\
\text { forms of expression in the modern/colonial world (p. 175) }\end{array}$ & $\begin{array}{l}\text { A political agenda to dismantle } \\
\text { power and knowledge founded } \\
\text { in the modern/colonial world. }\end{array}$ \\
\hline 2007 & Mignolo & $\begin{array}{l}\text { Decolonization is a critical response to colonization, and a propositional } \\
\text { stance to epistemic, Eurocentric, and hegemonic deconstruction that } \\
\text { is only achieved through a thought that exercises disobedience, both } \\
\text { politically and epistemically (p. 194). }\end{array}$ & $\begin{array}{l}\text { A political and epistemological } \\
\text { response to deconstruct and } \\
\text { disobey colonization. }\end{array}$ \\
\hline 2007 & Grosfoguel & $\begin{array}{l}\text { Decolonization seeks to make a border critical thinking emerge as a } \\
\text { critique of modernity towards a pluriversal transmodern decolonized } \\
\text { world, with multiple and diverse ethical-political projects, where there can } \\
\text { be real communication and horizontal dialogue with equality among the } \\
\text { peoples of the world, beyond the logics and practices of domination and } \\
\text { exploitation of the world-system (p. 74). }\end{array}$ & $\begin{array}{l}\text { A critique to advocate for a } \\
\text { pluriversal world infused with } \\
\text { symmetric communication } \\
\text { and dialogue. }\end{array}$ \\
\hline 2013 & Walsh & $\begin{array}{l}\text { Decolonization consists of organizational, analytical, and psychic } \\
\text { methodologies that guide ruptures, transgressions, displacements and } \\
\text { inversions of the concepts and practices imposed and inherited. And, on } \\
\text { the other hand, they are the central and constitutive component of the } \\
\text { decolonial itself, its conductor; what gives way and push to the processes } \\
\text { of disengagement and detachment, and what leads to situations of de(s) } \\
\text { colonization }\end{array}$ & $\begin{array}{l}\text { Methodologies to call } \\
\text { for contraventions and } \\
\text { disarticulations of imposed } \\
\text { concepts and inherited } \\
\text { practices. }\end{array}$ \\
\hline 2017 & Ballestrin & $\begin{array}{l}\text { Decolonization is a movement of theoretical and practical, political, and } \\
\text { epistemological resistance to the logic of modernity... [it] represents } \\
\text { a movement away from modernity and its inherent rationality, seeking } \\
\text { resistance praxis to colonial ideologies (p. 519). }\end{array}$ & $\begin{array}{l}\text { A movement of resistance } \\
\text { praxis against modernity and } \\
\text { its colonial ideologies. }\end{array}$ \\
\hline
\end{tabular}

\section{Source: Author}

The historical overview above allows noticing that decolonization is a theoretical construct that encompasses a conceptual move between a political stance and an epistemological perspective against the modern/colonial system and its colonial, hierarchical, homogeneous, and Eurocentric discourses, and practices. Not only does this construct help unveil epistemological silences against subalternate subjects and relations, but also it helps question patterns of knowledge and power instituted by colonialism. As a construct, decolonization resists restrictive discourses and enforced practices to enable new ethic-political and sociocultural interactions based on balanced contacts and parallel communication.

Attempting to offer a comprehensive definition of decolonialization, Gómez et al. (2017) define it as "critical theories that allow to propose other counterhegemonic discourses, which recognize new ways of envisioning and understanding the world in search of the transformation of naturalized and strategically invisible structures and power relations" (p. 48). Therefore, decolonization aims at creating new symbolisms and realities that allow deconstructing, on the one hand, subordinate subjectivities and, on the other, creating epistemic conditions for emancipation. To truly challenge hegemonic and discriminatory hierarchies, decolonization should generate theories that:

- are complementary as they integrate different types of studies to make culture a determining factor in social analysis;

- acknowledge other thinkings as they criticize hegemonic epistemologies and propose alternative knowledge;

- deconstruct coloniality as they question the colonialities of power, knowledge, and being;

- create possibilities for the appearance of intercultural and pluriversal forms of existence, knowledge, and power; and 
- $\quad$ offer new elements of discussion to traditional topics such as class, gender, and race.

\section{Decolonization and ELT in Colombia}

In the last years, several Colombian authors have started incorporating theoretical perspectives and adopting research approaches that help one realize that language is not an objective or neutral entity, but a subjective and biased construct, as well as to consider culture as a site of power struggle among dominant and subordinated groups. Within the framework of critical theory, Granados-Beltrán (2018) argues for the problematization of the geopolitics of knowledge production, the marginalization of the subaltern, and the enforcement of hierarchy and superiority. To him, the Colombian ELT community needs to

\begin{abstract}
become power literate and moving beyond contemplation and complaint to more concrete actions... encompassing new research questions, local materials development, recovery of local pedagogies and practices, and exploration of local contexts and participants (Granados-Beltrán, 2018, p. 189).
\end{abstract}

In a similar vein, but assuming the epistemologies of the South ${ }^{5}$, Castañeda (2018) argues in favor of personal and group reflections about how ELT is part of the process of colonialism in which the ideologies of the colonizers are superimposed on local practices and knowledges. To overcome this perpetuation of theories, methodologies, and techniques, he invites the Colombian ELT community to acknowledge "the presence of an ecology of knowledges that negotiates among those imposed knowledges and

5 In 2014, Santos defined the epistemologies of the South as "a set of inquiries into the construction and validation of knowledge developed by social groups as part of their resistance against the systematic injustices and oppressions caused by capitalism, colonialism, and patriarchy" (p. x). In 2019, he maintained that the epistemologies of the South enhance the world's cognitive diversity while simultaneously setting up procedures aimed at promoting inter-knowledge and inter-intelligibility... Instead of polarization or the dogmatism of absolute opposition, so frequent in academic disputes, the epistemologies of the South choose to build bridges between comfort zones and discomfort zones and between the familiar and the alien in the fields of struggle against oppression (p. xviii). the local ones, and that provides a wider vision of what to teach and how to teach in English" (Castañeda, 2018, p. 174). Finally, adopting critical interculturality, Núñez-Pardo (2020) claims that neither does the production of ELT materials in Colombia comprise the complexity of the local contexts and communities, nor it truly promotes awareness and sensitiveness to sociocultural diversity across the world. To alleviate this condition, she calls for 'students' and teachers' resistance to hegemony, a search for their critical sociopolitical awareness, a committed agency, and generation of local knowledge, so that subaltern communities are considered as the locus for other epistemologies" (Núñez-Pardo, 2020, p. 123).

Following the footsteps of my colleagues, I am in favor of resorting to Kumaravadivelu (2016), when he argues that teachers are subalterns subjected to center-based methods and centerproduced materials driven by a hegemonic power structure that controls them through curricular plans, teaching methods, standardized tests, and teacher education. This situation demands them to be organic intellectuals ${ }^{6}$ whose work goes beyond the confines of the institutionalized hegemonic order by advocating for the transformation of their subalternatized communities. When challenging hegemonic structures, ELT organic intellectuals find themselves decolonizing structures, discourses, and practices as part of "a long-term process... from below and from within... of resignification and re-construction towards words and knowledges otherwise" (Escobar, 2010, as cited in Kumaravadivelu, 2016, p. 79). To him, such decolonization implies two different, but complementary processes: delinking and epistemic break. The former refers to "unfreezing the subaltern's potential for thinking otherwise... to denaturalize concepts and conceptual fields

6 Following Gramsci (1989), Kumaravadivelu (2016) distinguishes between traditional intellectuals and organic intellectuals. Traditional intellectuals live in institutions within the hegemonic order and are not concerned with helping members of the subaltern communities. For their part, organic intellectuals commit to the transformation of subaltern communities by formulating counterhegemonic ideas and practices. Such ideas and practices lead them to embark on "result-oriented action that can transform relations of subordination and domination" (Kumaravadivelu, 2016, p. 77). 
set by hegemonic forces" (Kumaravadivelu, 2016, p. 79) whereas the latter refers to "a thorough reconceptualization and a thorough re-organization of knowledge systems... new epistemological orientations appear with a considerable degree of regularity" (Kumaravadivelu, 2012, p. 14).

The denaturalization of concepts and the reorganization of knowledge systems inspires ELT organic intellectuals to create what Mignolo (2010) calls a grammar of decoloniality. A commitment to learning to unlearn the discursive and cultural colonialities of knowledge, being, and power. More concretely, Mignolo (2010) states that this grammar of decoloniality

is initiated with the recognition, in the first place, that the colonialization of knowledge and being consists of using imperial knowledge to repress colonized subjectivities and the process moves from there to build structures of knowledge that emerge from the experience of humiliation and marginalization that have been and continue to be enacted by the implementation of the colonial matrix of power (p. 346).

To Kumaravadivelu, a grammar of decoloniality is "a framework for strategic plans drawn by subalterns deriving from their own lived experiences and hence it will vary from context to context" (2012, p. 79). Such grammar must be formulated and implemented by local players who know local conditions and commit to orchestrating concerted and collective actions. Initially, he postulates that such a framework can involve

- the design of context-specific instructional strategies based on local sociocultural, historical-political, and educational needs;

- the preparation of teaching materials that, beyond satisfying teaching and language goals, meet the instructional strategies designed by local professionals;

- the development of proactive research that reduces the dependency on center-based knowledge systems; and

- the restructuring of teacher education programs, so that future teachers become producers of pedagogical knowledge.

\section{A grammar of decoloniality for English language teaching in Colombia}

In my opinion, a grammar of decoloniality must help Colombian ELT professionals question the ways in which colonialism impacts their lives as subjects of this disciplinary field. It should help them elaborate alternative narratives about the pedagogical, curricular, communicative, historical, and cultural constructs that inform their conceptualizations, experiences, and sensitivities as language teachers. Ultimately, it should enable them to face "the struggle for the decolonization of knowledge and epistemology, facing a praxis that ponders about decoloniality in theoretical and also ethical and political terms" (Goulart, 2016, p. 58).

Here, I agree with Rocha et al. (2019) when they claim that the decolonization of ELT and the use of a grammar of decoloniality must enable new meanings to ELT education to "destabilize top-down hierarchical power and knowledge relationships" (p. 349). To me, three decolonial efforts are of particular interest for our community:

1. Spaces of speech: opportunities for the ELT community to engage in a pluralistic and dialogical logic that facilitates the emergence of different knowledges and the construction of other knowledges.

2. Flattened hierarchy: activities in which the ELT community commits to decentralizing epistemic responsibilities and roles as well as to destabilizing unbalanced knowledge/power relations.

3. Teacher agency: a commitment in the ELT community for its teachers to build and share attitudes towards their active involvement in the professional context.

Going beyond the analysis and transformation of language policies and curricular projects, I claim that these decolonial efforts should motivate Colombian ELT professionals to construct collegial processes that resist and question subalternizing forms of power, knowledge, and being. In parallel, these decolonial efforts should enable these professionals to infuse their pedagogical praxis with undiscipline, disobedient, and emancipatory 
teaching actions. Thus, I concur with Walsh (2007) when she maintains that decoloniality should empower teachers in such ways that we can

build educational processes that make us think and act critically, confronting, and challenging the dominant relationships and structures and, at the same time, moving towards the development and implementation of a pedagogy and praxis not only critical but also decolonial (p. 26).

Now, to achieve spaces of speech, flattened hierarchy, and teacher agency, I propose a grammar of decoloniality as follows:

In the next paragraphs, I present some preliminary ideas on how to go about an interrelated development of the three decolonialities that appear to integrate the grammar of decoloniality. They are proposed as possibilities and alternatives for teachers and their collectivities to ponder about. By no means should they be regarded as static and fixed impositions. Instead, they should be treated as open and flexible doorways to reflection, discussion, and transformation. In addition, this grammar should not be regarded as a schematic model, but as a dynamic one open to interconnections and feedback loops.

In the first place, I understand the decoloniality of power as an ethical-political commitment to providing teachers with teacher empowerment. As a power process, teacher empowerment allows teachers to problematize their pedagogical and professional knowledge, so that they can take ownership of their practice and improve their reality (Asunción, 2019). To this end, teachers need to learn to acquire and develop attitudes as leaders and researchers, which equip them to innovate their praxis and reconstruct their contexts. As a result, EFL teachers are invited to be actors who

analyze the foundations and the processes from which knowledge about teaching is derived, who recognize the different forms of argumentation and who privilege the life of the those learning, in such ways that they favor the appearance of various contextualized rationalities and change their relationship to the knowledge of their profession (Asunción, 2019, p. 11).

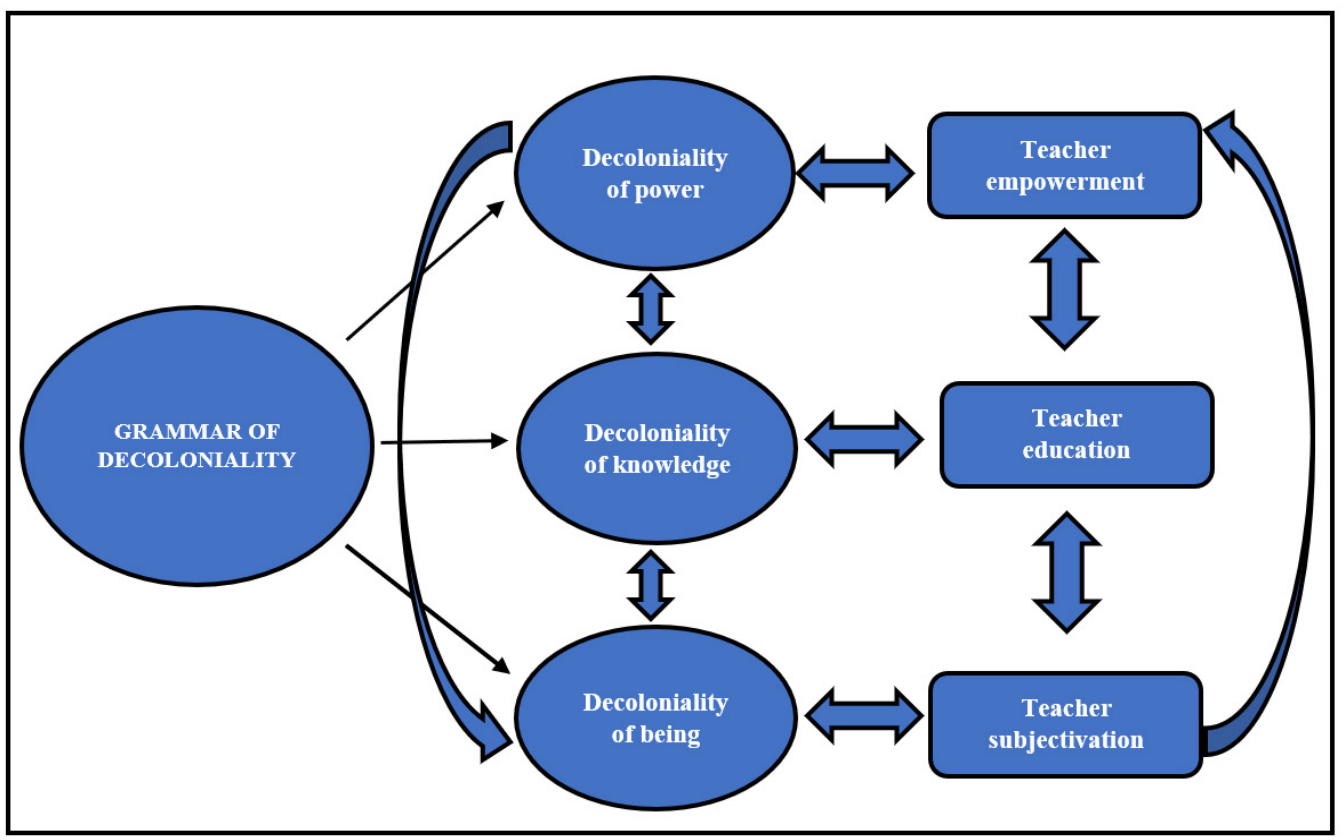

Figure 1. A grammar of decoloniality in ELT Source: Author 
Next, I understand the decoloniality of knowledge as a pedagogical-intellectual effort to move teacher education away from top-down educational policies and one-size-fits-all curricular innovations. Such move means regarding teacher education as a process of individual fulfillment, as well as one of social construction, through which the teacher-subject appropriates socio-cultural modes and theoreticalpractical forms relevant to their educational institutions (Villegas, 2014). Teacher education must be therefore constituted as a formative experience that provides explanatory keys and understanding horizons, which allow understanding the construction of teachers' work, the establishment of their educational reality, and the foundation of their professional canons. When regarded as a pedagogical-intellectual formative experience, teacher education can allow ELT professionals to understand, among other things, how they should go from "representing themselves as oppressed social subjects among others to recognizing themselves as an intellectual or cultural worker, whose pedagogical and intellectual capacities have been relegated by an epistemological-political regime of knowing" (Saldarriaga and Vargas, 2015. p. 314).

Finally, I assume the decoloniality of being as an ontological-hermeneutic reinterpretation of what becoming a teacher implies. Becoming subjects as teachers implies conceiving them as actors with identity, consciousness, and self-determination, capable of "an exercise of power over themselves, as an ethical attitude, of caring for themselves and others, with which a way of life or an art of existence is given form (Foucault, 2005, p. 60). Such conception incites ELT professionals to understand their teacher subjectivation as "an art of living based on desubjugation to constitute themselves as beings different from what they have been given to think, in pursue of other forms of thinking, being, and acting" (Plata, 2018, p. 297). In this way, teacher subjectivation seeks, on the one hand, to make visible and denaturalize conditions and practices of subjection (power logic and dispositifs that define, discipline, and shape practices of self) and, on the other, to enhance and legitimize possibilities and alternatives of subjectivation (power logic and dispositifs that subvert, insubordinate, and challenge practices of self). By denaturalizing practices of subjection and enhancing alternative selves, teacher subjectivation can become a category that highlights the diversity of particular and unprecedented forms that teachers exhibit in their daily lives to deliberately contest the status quo. Ultimately, a contestatory and transgressive teacher subjectivation can help ELT teachers "exercise agency that in their own way removes the force of the power relations instituted so they can re-intervene, reorient and reconvert the forms of relationship with themselves and with others with the purpose of co-creating heterogeneous ways of being and multiple ways of living them" (Salcedo, 2017, p. 106).

\section{Conclusion}

As it was explained, colonialism consists of the political, economic, and cultural hegemony and domination of the colonizers over the minds, bodies, and hearts of the colonized. Beyond forced entries and exploitation of resources, colonialism establishes a status quo that elevates the knowledge, culture, and practices of the colonizers while degrading those of the colonized. The relationship between the superior colonizer and the inferior colonized promoted by colonialism is further consolidated by discriminating narratives and practices that segregate and minimize subjectivities, knowledges, and autonomies.

In ELT, colonialism manifests itself in many ways that preserve the limited but naturalized practices supported and expanded by the global north. Initially, there is a generalized approval of the notion that English is the language to teach and learn over other languages. On the other hand, there is an unquestionable acceptance of the importance of using teaching methods and materials produced by western academia. Similarly, there is a problematic tolerance of exclusion and inequality represented by teacher certification and foreign language marketization. As a result of these and other colonial mechanisms, Samacá (2020) argues that

we, English teachers, have been denied being ourselves, because the nature of our profession has been conceived by Western thought. We have forgotten about ourselves as we have been 
subjected to Westernized theories. We have not thought about English language teaching from our local perspectives (p. 171).

This paper has argued that this situation requires the Colombian ELT community to exercise and commit to decolonization as "a processes through which those who do not accept to be dominated and controlled do not only work to get rid of coloniality, but also to construct social, local and world organizations that are not submissive and controlled" (Mignolo, 2012, p. 148). Through delinking, epistemic break, spaces of speech, flattened hierarchy, teacher agency, and a systematic and consistent work with a grammar of decoloniality, ELT intellectuals can indiscipline research agendas, curricular projects, and language policies to engage in personal and collective meaning-making and dialogues that allow them to open new opportunities with knowledge and to find alternative ways of being and acting in the world. It follows, then, that decolonization can help the Colombian ELT community realize that it needs to re-center itself, both intellectually and culturally, by deconstructing dominant structures and strategies which promote the world views of the global north. Ultimately, by decolonizing ELT in Colombia, teacher education programs can open room and space for a teacher subjectivation that enables us

to question, to wonder, to re-think and retheorize how, what, and why we practice, teach, and research the way we do... to exercise a systematic rejection of colonialism through a critical encounter and gaze at the dominance and hegemonic knowledge, representation, and theory used in teaching and learning within education (Absolon, 2019, p. 17).

\section{References}

Absolon, K. (2019). Decolonizing Education and Educators' Decolonizing. Intersectionalities: A Global Journal of Social Work Analysis, Research, Polity, and Practice, 7(1), 9-28. https://journals. library.mun.ca/ojs/index.php/IJ/article/view/2073

Ahuja, N. (2017). Colonialism. In S. Adamo (Ed.), Gender: Matter (pp. 237-251). MacMillan Reference USA.
Ashcroft, B., Griffitths, G., \& Tiffin, H. (2007). Postcolonial studies. Key concepts ( ${ }^{\text {nd }}$ ed.). Routledge.

Asunción, S. (2019). Metodologías Activas: Herramientas para el empoderamiento docente. Revista TecnológicaEducativa Docentes 2.0 (RTED), 19(1), 1-16.

Ballestrin, L. M. (2017). Modernidade/Colonialidade sem "Imperialidade"? O El Perdido do Giro Decolonial. Dados, 60(2), 505-540. https://doi. org/10.1590/001152582017127

Böröcz, J., E Sarkar, M. (2012). Colonialism. In H. Anheier, M. Juergensmeyer, \& V. Faessel (Eds.), Encyclopedia of Global Studies (pp. 229-234). SAGE. https://doi. org/10.4135/9781452218557.n75

Bourdieu, P. (1991). Introduction. In J. Thompson (Ed), Language and symbolic power (pp. 37-42). Harvard University Press.

Branschat, F. (2019). Maximizing Colombia's linguistic capital with the knowledge of linguistic imperialism and linguistic human rights [Master's thesis, Universidad ICESI]. http://repository.icesi.edu.co/ biblioteca_digital/handle/10906/85547

Canagarajah, S. (2000). Negotiating ideologies through English: Strategies from the periphery. In T. Ricento (Ed.), Ideology, politics, and language policies: Focus on English (pp. 121-132). John Benjamins. https://doi.org/10.1075/impact.6.10can

Castañeda, J. (2018). Voices from the south: English Language Pre-Service Teachers contributions to ELTE. In H. Castañeda, C. Guerrero, P. Méndez, A. Castañeda, A. Dávila, C. Arias, E. Lucero, J. Castañeda, J. Zoraida, \& Y. Samacá (Comps.), ELT local research agendas I (pp. 159-178). UD editorial.

Charles, E. (2019). Decolonizing the Curriculum. Insights, 32(1), 1-7. http://doi.org/10.1629/uksg.475

Davis, T. (2012). Globalisation and the North/South Divide: An Overview. In R. Pettman (Ed.), Handbook on International Political Economy (pp. 231-247). World Scientific Publishing Co. Pte. Ltd. https://doi. org/10.1142/9789814366984_0015

De Castro, J. (2014). Colonialism and postcolonialism. In C. Mitcham (Ed.), Encyclopedia of science, technology, and ethics (pp. 383-390). Gale Virtual Reference.

Foucault, M. (2005). La hermenéutica del sujeto. Ediciones Akal.

Gómez, M., Saldarriaga, D., López, M., \& Zapata, L. (2017). Estudios decoloniales y poscoloniales. Posturas acerca de la modernidad/colonialidad y el eurocentrismo. Revista Ratío Juris, 12(24), 27-60. https://doi.org/10.24142/raju.v12n24a2

Goulart, S. (2016). A story told in a whisper, or the impossibility of atonement. Ilha do Desterro, 69(2), 
57-62. https://www.scielo.br/j/ides/a/7rgw6mkmssjc3 $\mathrm{rgX} 4 \mathrm{bXsK6 \textrm {b } / \text { ?lang } = \mathrm { en }}$

Gramsci, A. (1989). Selections from the Prison Notebooks. International Publishers Co.

Granados-Beltrán, C. (2018). Revisiting the need for critical research in undergraduate Colombian English language teaching. HOW Journal, 25(1), 174-193. https://doi.org/10.19183/how.25.1.355

Grosfoguel, R. (2007). Descolonizando los universalismos occidentales: el pluri-versalismo transmoderno decolonial. In S. Castro-Gómez \& R. Grosfoguel (Eds.), El giro decolonial. Reflexiones para una diversidad epistémica más allá del capitalismo global (pp. 63-78). Siglo del Hombre Editores.

Guerrero, C. E. (2010). Is English the key to access the wonders of the modern world? A Critical Discourse Analysis. Signo y Pensamiento, 29(57), 294-313. https://www.redalyc.org/articulo. oa?id $=86020052019$

Guerrero, C. E. (2018). Problematizing ELT education in Colombia: Contradictions and possibilities. In $\mathrm{H}$. Castañeda, C. Guerrero, P. Méndez, A. Castañeda, A. Dávila, C. Arias, E. Lucero, J. Castañeda, J. Zoraida, E Y. Samacá (Comps.), ELT local research agendas I (pp. 121-132). UD editorial.

Hasan Al-Saidi, A. (2014). Post-colonialism Literature the Concept of self and the other in Coetzee's Waiting for the Barbarians: An Analytical Approach. Journal of Language Teaching and Research, 5(1), 95-105. https://doi.org/10.4304/jltr.5.1.95-105

Hsu, F. (2017). Revisiting the coloniality of English: A research review of strategies. The CATESOL Journal, 29(1), 111132. https://files.eric.ed.gov/fulltext/EJ1144339.pdf

Kachru, B. (1985). Standards, codification, and sociolinguistic realism: English language in the outer circle. In R. Quirk \& H. Widowson (Eds.), English in the world: Teaching and learning the language and literatures (p. 11-36). Cambridge University Press.

Kumaravadivelu, B. (2012). Individual identity, cultural globalization, and teaching English as an international language: The case for an epistemic break. In L. Alsagoff, S. McKay, G. Hu, \& W. Renandya (Eds.), Teaching English as an international language: Principles and practices (pp. 9-27). Routledge.

Kumaravadivelu, B. (2016). The Decolonial Option in English Teaching: Can the Subaltern Act? TESOL Quarterly, 50(1), 66-85. https://doi.org/10.1002/ tesq.202

Le Gal, D. (2019). English Language Teaching in Colombia: A Necessary Paradigm Shift. Matices en Lenguas Extranjeras (MALE), 12, 156-190. https:// doi.org/10.2139/ssrn.3420094
Loos, E. (2000). Language choice, linguistic capital, and symbolic domination in the European Union. Language problems and language planning, 24(1), 37-53. https://doi.org/10.1075/lplp.24.1.04loo

Maldonado, N. (2006). Aimé Césaire y la crisis del hombre europeo. In A. Césaire (Ed.), Discurso sobre el coloniamismo (pp. 173-196). Ediciones Akal.

Masta, S. (2016). Disrupting Colonial Narratives in the Curriculum. Multicultural Perspectives, 18(4), 185191. https://doi.org/10.1080/15210960.2016.12224 97

Mignolo, W. (2007). La idea de América Latina. La herida colonial y la opción decolonial. Gedisa.

Mignolo, W. (2010). Delinking: The rhetoric of modernity, the logic of coloniality and the grammar of decoloniality. In W. Mignolo \& A. Escobar (Eds.), Globalization and the decolonial option (pp. 303368). Routledge.

Mignolo, W. (2012). Estéticas decoloniales. In L. Cortés (Ed.), Arte + Política. Pensamientos críticos en época de crisis (pp. 133-161). UD Editorial.

Núñez-Pardo, A. (2020). Inquiring into the Coloniality of Knowledge, Power, and Being in EFL Textbooks. HOW Journal, 27(2), 113-133. https://www. howjournalcolombia.org/index.php/how/article/ view/566/551

Pennycook, A. (1998). English and the discourses of colonialism. Routledge.

Pennycook, A. (2007). ELT and colonialism. In J. Cummins E C. Davison (Eds.), International handbook of English language teaching (pp. 13-24). Springer. https://doi.org/10.1007/978-0-387-46301-8 2

Phillipson, R. (2009). Linguistic imperialism continued. Routledge.

Pirbhai-Illich, F., Osber, D., Martin, F., Chave, S., Sabbah, M., \& Griffiths, H. (2017). Decolonizing Teacher Education: Re-thinking the Educational Relationship Research Seminar Report. Canada-UK Foundation.

Pishghadam, R., E Zabihi, R. (2012). Crossing the threshold of Iranian TEFL. Applied Research on English Language, 1(1), 57-71. https://doi. org/10.22108/are.2012.15446

Plata, M. (2018). Subjetividades docentes en tiempos de la excelencia educativa. Colombian Applied Linguistics Journal, 20(2), 290-302. https://doi. org/10.14483/22487085.12624

Rocha, R., Viana, V., E Vilarinho, J. (2019). Challenges of a decolonial undertaking in teacher education. Calidoscópio, 17(2), 342-360. https://doi. org/10.4013/cld.2019.172.07 
Roth, S. (2019). Linguistic capital and inequality in aid relations. Sociologial research online, 24(1), 38-54. https://doi.org/10.1177/1360780418803958

Salcedo, J. (2017). Reformas educativas y modos de subjetivación de docentes universitarios. Caso universidad de La Salle de Bogotá [Doctoral thesis, Universidad Pedagógica Nacional]. http://hdl.handle. net/20.500.12209/9295

Saldarriaga, Ó., E Vargas, C. (2015). La configuración histórica del maestro público en Colombia: Entre opresión y subalternidad, 1870-2002. Historia y Memoria de la Educación, 1(1), 287-318. https:// doi.org/10.5944/hme.1.2015.13277

Samacá, Y. (2020). Towards A Decolonial Project: A Quest between ELT Colonial Ideologies in the ELTP and the Interrelations among Its Subjects. In $\mathrm{H}$. Castañeda, C. Guerrero, P. Méndez, A. Castañeda, A. Dávila, C. Arias, E. Lucero, J. Castañeda, J. Zoraida, \& Y. Samacá (Comps.), Methodological uncertainties of research in ELT education I (pp. 163-182). UD Editorial.

Santos, B. S. (2016). Epistemologies of the south. Justice against epistemicide. Routledge.

Santos, B. S. (2020). Introduction. In B. S. Santos \& M. P. Meneses (Eds.), Knowledge born in the struggle. Constructing the epistemologies of the Global South (pp. xvii-xliii). Taylor and Francis. https://doi. org/10.1007/978-3-658-29111-2_2

Sekhar, G. R. (2012). Colonialism and imperialism and its impact on English language. Asian Journal of Multidimensional Research (AJMR), 1(4), 111120. https://tarj.in/images/download/ajmr/AJMR\%20 SEPTEMBER September $\% 202012 \% 20$ PAPERS $\% 20$ PDF/AJMR\%20SEPTEMBER\%202012\%20 PAPERS\%20PDF/9.9,\%20G\%20Rajasekhar.pdf
Sommer, M. (2011). Colonies, colonization, colonialism: A typological reappraisal. AWE, 10, 183-193. https:// doi.org/10.2143/AWE.10.0.2141818

Soto-Molina, J. E., \& Méndez, P. (2020). Linguistic Colonialism in the English Language Textbooks of Multinational Publishing Houses. HOW Journal, 27(1), 11-28. https://doi.org/10.19183/how.27.1.521

Thielsch, A. (2019). Listening out and dealing with otherness. A postcolonial approach to higher education teaching. Arts and humanities in higher education, 9(2), 227-243. https://doi. org/10.1177/1474022219832459

Torres-Rocha, J. C. (2019). EFL Teacher Professionalism and Identity: Between Local/Global ELT Tensions. HOW Journal, 26(1), 153-176. https://doi. org/10.19183/how.26.1.501

Valtonen, K. (2016). Social Work and Migration: Immigrant and Refugee Settlement and Integration. Routledge. https://doi.org/10.4324/9781315609669

Veronelli, G. (2015). Sobre la colonialidad del lenguaje. Universitas humanística, 81(81), 33-58. https://doi. org/10.11144/Javeriana.uh81.scdl

Villegas, M. (2014). La perspectiva histórico-cultural y su impacto sobre la investigación de la docencia. Revista actualidades investigativas en educación, 14(1), 1-17. https://doi.org/10.15517/aie.v14i1.13386

Walsh, C. (2007). Interculturalidad, colonialidad y educación. Revista Educación y Pedagogía, 19(48), 25-35. https://revistas.udea.edu.co/index.php/ revistaeyp/article/view/6652

Walsh, C. (2013). Lo pedagógico y lo decolonial. Entretejiendo caminos. In C. Walsh (Ed.), Pedagogías decoloniales. Práctica insurgents de resistir, (re)existir y (re)vivir. Tomo I (pp. 23-68). Ediciones Abya-Yala. 